\title{
Coupling of a sediment diagenesis model (MEDUSA) and an Earth system model (CESM1.2): a contribution toward enhanced marine biogeochemical modelling and long-term climate simulations
}

\author{
Takasumi Kurahashi-Nakamura ${ }^{1}$, André Paul ${ }^{1}$, Guy Munhoven ${ }^{2}$, Ute Merkel ${ }^{1}$, and Michael Schulz ${ }^{1}$ \\ ${ }^{1}$ MARUM - Center for Marine Environmental Sciences and Faculty of Geosciences, \\ University of Bremen, Bremen, Germany \\ ${ }^{2}$ Laboratoire de Physique Atmosphérique et Planétaire, Université de Liège, Liège, Belgium
}

Correspondence: Takasumi Kurahashi-Nakamura (tkurahashi@marum.de)

Received: 20 August 2019 - Discussion started: 7 October 2019

Revised: 27 January 2020 - Accepted: 3 February - Published: 2 March 2020

\begin{abstract}
We developed a coupling scheme for the Community Earth System Model version 1.2 (CESM1.2) and the Model of Early Diagenesis in the Upper Sediment of Adjustable complexity (MEDUSA), and explored the effects of the coupling on solid components in the upper sediment and on bottom seawater chemistry by comparing the coupled model's behaviour with that of the uncoupled CESM having a simplified treatment of sediment processes. CESM is a fully coupled atmosphere-ocean-sea-ice-land model and its ocean component (the Parallel Ocean Program version 2 ; POP2) includes a biogeochemical component (the Biogeochemical Elemental Cycling model; BEC). MEDUSA was coupled to POP2 in an offline manner so that each of the models ran separately and sequentially with regular exchanges of necessary boundary condition fields. This development was done with the ambitious aim of a future application for long-term (spanning a full glacial cycle; i.e. $10^{5}$ years) climate simulations with a state-of-the-art comprehensive climate model including the carbon cycle, and was motivated by the fact that until now such simulations have been done only with less-complex climate models. We found that the sediment-model coupling already had nonnegligible immediate advantages for ocean biogeochemistry in millennial-timescale simulations. First, the MEDUSAcoupled CESM outperformed the uncoupled CESM in reproducing an observation-based global distribution of sediment properties, especially for organic carbon and opal. Thus, the coupled model is expected to act as a better "bridge" between climate dynamics and sedimentary data, which will provide
\end{abstract}

another measure of model performance. Second, in our experiments, the MEDUSA-coupled model and the uncoupled model had a difference of $0.2 \%$ or larger in terms of $\delta^{13} \mathrm{C}$ of bottom water over large areas, which implied a potentially significant model uncertainty for bottom seawater chemical composition due to a different way of sediment treatment. For example, an ocean model that does not treat sedimentary processes depending on the chemical composition of the ambient water can overestimate the amount of remineralization of organic matter in the upper sediment in an anoxic environment, which would lead to lighter $\delta^{13} \mathrm{C}$ values in the bottom water. Such a model uncertainty would be a fundamental issue for paleo model-data comparison often relying on data derived from benthic foraminifera.

\section{Introduction}

For Earth system models, the simulation of biogeochemical cycles in the ocean is of fundamental importance. Simulating biogeochemistry is important for the projection of unknown (e.g. future) climate states in a prognostic way, because the biogeochemical cycles play an active role in the climate system by changing greenhouse-gas concentrations in the atmosphere particularly through the carbon cycle. Secondly, biogeochemical tracers are an important indicator of water masses, and thus a measure of the model quality in representing ocean structures when comparing model states with observations and reconstructions. The distribution of 
T. Kurahashi-Nakamura et al.: CESM-MEDUSA coupling

biogeochemical matter in the ocean is determined by internal processes (e.g. physical volume transport, mixing of seawater, and the biological pump) and processes at the upper and lower boundaries. The latter factors, boundary conditions in terms of numerical modelling, consist of two aspects (e.g. Kump et al., 2000; Ridgwell and Zeebe, 2005): the inflow of matter as riverine input following chemical weathering on land (i.e. the upper boundary condition) and the net outflow of marine matter at the ocean floor into sediments (i.e. the lower boundary condition). This study focused on explicitly simulating the processes at the lower boundary, that is, the exchange of biogeochemical matter between the seawater and ocean-floor sediments, which motivated the coupling of a climate model including an ocean biogeochemical component and a process-based sediment model dealing with early diagenesis in sediments. Coupling a sediment model is expected to lead to a better simulation of the seawater isotopic composition especially for bottom water by providing more realistic lower boundary conditions to an ocean model. This would be particularly important when the climate model is applied to various climate states because a substantial amount of paleoceanographic data is provided by isotopic measurements. In addition to the effects on seawater chemistry, the sediment model will allow to compare models and sedimentary records directly.

To simulate the sedimentary diagenesis, different modelling approaches with a variety of complexity have been used for paleoclimatological or global biogeochemical studies (Soetaert et al., 2000; Hülse et al., 2017), which include a reflective boundary approach where all the sinking particles that reach the sediments are dissolved in the deepest ocean grid cells (e.g. Yamanaka and Tajika, 1996; Marchal et al., 1998), a vertically integrated reaction layer approach (e.g. Goddéris and Joachimski, 2004; Ridgwell and Hargreaves, 2007), and an approach with a vertically resolved transient diagenetic model (e.g. Heinze et al., 1999; Munhoven, 2007; Tschumi et al., 2011). In this study, we aim at advancing Earth system modelling by coupling a comprehensive climate model, as opposed to an Earth system model of intermediate complexity (EMIC), including an ocean general circulation model with a vertically resolved sediment model dealing with fully coupled reaction-transport equations. To our knowledge, a fully coupled comprehensive climate model including a sediment diagenesis model has been applied to millennial timescales only (Jungclaus et al., 2010). We are planning to apply such a model to timescales of tens of millennia with the goal of simulating glacial-interglacial variations. Here, we report on technical aspects of the coupling and assess the immediate influence of sedimentary processes on the bottom-water chemistry. The assessment is important because it reveals possible model errors or biases of marine biogeochemical simulations that depend on the treatment of sedimentary processes in a climate/ocean model. We also discuss possible future applications of the coupled model for studies dealing with the long-term evolution of climate.

\section{Methods}

\subsection{Models}

For the climate part of the coupled model, we employed the Community Earth System Model (CESM; Hurrell et al., 2013; version 1.2). CESM1.2 is a fully coupled atmosphereocean-sea-ice-land model, and the ocean component is the Parallel Ocean Program version 2 (POP2). In this study, POP2 was configured to include the Biogeochemical Elemental Cycling model (BEC; Moore et al., 2004, 2013; Lindsay et al., 2014). The BEC model is a nutrientphytoplankton-zooplankton-detritus (NPZD)-type marine ecosystem model and contains a parameterized routine for sinking processes of biological particles including particulate organic matter (POM) with the "ballast effect" based on Armstrong et al. (2002). The BEC model also includes a highly simplified empirical treatment of dissolution of particulate matter at the ocean floor. For particulate organic carbon (POC) and opal, the amount of dissolved matter given back to the seawater is empirically determined based on Dunne et al. (2007) for POC and Ragueneau et al. (2000) for opal, and the residual matter corresponding to burial is simply lost from the model domain. As to calcite, all particles that reach the ocean floor above a prescribed depth level $(3300 \mathrm{~m})$ are lost from the model domain, and all particles dissolve below that level. This original version of CESM with the simplified model for particle dissolution at the ocean floor was used for comparison with the CESM coupled to our sediment module.

The ocean model was also extended with the carbonisotope component developed by Jahn et al. (2015), so that we were able to simulate explicitly the carbon-isotope composition of seawater, which is an important biogeochemical tracer from a paleoceanographic viewpoint. In this study, a low-resolution setup of CESM following Shields et al. (2012) was used. The ocean component had a nominal $3^{\circ}$ irregular horizontal grid with 60 layers in the vertical, while the atmosphere component, the Community Atmosphere Model version 4 (CAM4), had a T31 spectral dynamical core (horizontal resolution of $3.75^{\circ}$ ) with 26 layers in the vertical. The comparatively fine vertical resolution of POP2 (e.g. 200 to $250 \mathrm{~m}$ resolution for the depths deeper than $2000 \mathrm{~m}$ ) allowed a better representation of bottom-water properties, which was particularly important in this study's context. Although only the low-resolution case is shown in this study, a similar procedure will be applicable also to a higher resolution configuration for future applications.

For the sediment model part, we adopted the Model of Early Diagenesis in the Upper Sediment of Adjustable complexity (MEDUSA; Munhoven, 2007). Note that this model is different from the marine ecosystem model with the same acronym (Yool et al., 2013). MEDUSA is a transient onedimensional advection-diffusion-reaction model that, in its original setup, describes the early diagenetic processes that affect carbonates and organic matter (OM) in the surface 
sediment of $10 \mathrm{~cm}$ thickness (see also Fig. 2 in Munhoven, 2007). In the $10 \mathrm{~cm}$ thick surface "reactive" sediment, solids are transported by bioturbation and advection, and solutes by molecular diffusion. Solids that get advected across the lower boundary of this $10 \mathrm{~cm}$ thick sediment get preserved (buried) on a stack of $1 \mathrm{~cm}$ thick layers that can be interpreted as a sediment core. The old deposits in the stack layers are treated as being not reactive any longer in the model. The thickness of the surface reactive layer is always kept at $10 \mathrm{~cm}$, and in case the net budget of solid material reduces the thickness to less than $10 \mathrm{~cm}$, some old material from the stack layers will be "revived" to compensate for the loss in the reactive layer and to keep the $10 \mathrm{~cm}$ thickness. In the coupled model, one MEDUSA column was coupled to the deepest grid cell of each POP2 water column and there was no lateral exchange of information among the MEDUSA columns.

In this study, MEDUSA was configured such that it treated explicitly eight solid components and nine solute components (Fig. 1), which is a substantial enhancement compared to the original setup in Munhoven (2007). For the calciumcarbonate species, only calcite was taken into consideration, in line with the BEC model, although MEDUSA is able to deal with aragonite as well. The time evolution of those chemical species was governed by five processes (Fig. 1): the oxic and suboxic degradation of POM, calcite dissolution, opal dissolution, and the radioactive decay of ${ }^{14} \mathrm{C}$. Subject to boundary conditions (i.e. downward solid fluxes, solute concentrations, and physical properties) at the top of the sediment stack, the model forecasts the vertical profiles of solid and solute components in 21 vertical layers. The solute concentrations in the deepest grid cells of POP2 were explicitly provided to MEDUSA except for calcium-ion concentration, which was empirically derived from the salinity. MEDUSA then returns solute fluxes at the sediment-water interface back to the water column.

\subsection{Coupling procedures}

The communication between the two models was done in a so-called "offline" manner; that is to say, we kept the executables of both models separate and exchanged necessary information for their boundary conditions through file exchange. We adopted the offline coupling considering the much longer characteristic timescale of the sediment model (e.g. a model time step in Munhoven, 2007 is 100 years) compared to that of the climate model. The offline method allowed manageability of model development and maintenance while being physically credible at the same time. However, although we could keep a substantial portion of the original structure of each model especially for the technical procedures (e.g. interfaces to drive the models and input/output routines), it was still required for us to make major alterations to both models and to develop new routines to realize the coupling, as follows:

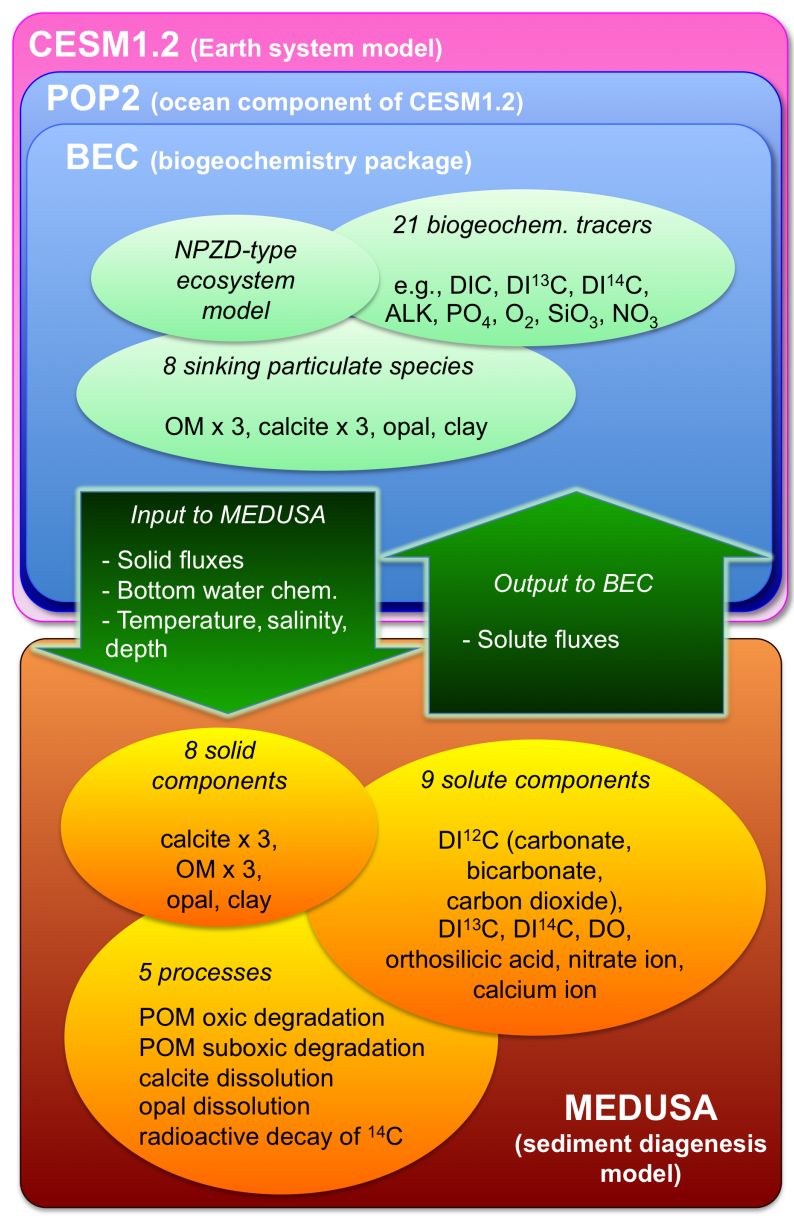

Figure 1. A schematic illustration of this study's coupling scheme. In the list of chemical species, "D" stands for "dissolved" and "I" for "inorganic"; for example, DO means dissolved oxygen and DIC dissolved inorganic carbon. OM stands for organic matter. Each of $\mathrm{OM}$ and calcite components had three categories (for ${ }^{12} \mathrm{C},{ }^{13} \mathrm{C}$, and $\left.{ }^{14} \mathrm{C}\right)$, and they were treated as separate tracers.

- Modifying POP2 involves

- introduction of new variables for the matter exchanged with MEDUSA as shown in Fig. 1;

- adjusting writing/reading routines for boundary conditions describing the additional variables;

- modifying source/sink terms in the tracer prognostic equations for the bottom grid cells of the ocean model; and

- changing the formulation of the boundary conditions at the ocean floor for the particulate matter.

- Modifying MEDUSA involves

- creating writing/reading routines for boundary conditions; and

- unit conversion for variables to be exchanged with POP2. 
- Interfaces between the two models include

- format adjustment for the input/output files to utilize the existing schemes of both models as much as possible; and

- automation of procedures: routines for each step of one-time coupling and a wrapper-level routine to repeat them.

For the coupling, CESM and MEDUSA were run sequentially as in the coupling between the atmosphere and ocean components of CESM (Craig et al., 2012); that is to say, each model was driven based on the state calculated by the other in the previous integration period. Otherwise, we would have needed an iterative way to obtain a convergence of fluxes between the two models that satisfied both of them for the same time period. That would have required significantly more development work and would have increased computational costs as well, and could be a subject of a future study.

\subsection{Experiments and analyses}

First, we spun up the two models. CESM was initialized with the model state at the 507th year of the preindustrial run with the same resolution using the Community Climate System Model version 4 (CCSM4, the model preceding CESM1.2) by Shields et al. (2012). Then the model was run for 200 years with an increased tracer time step for the deep ocean (Danabasoglu et al., 1996). The tracer time step $(\sim 2 \mathrm{~h}$ for the surface) was increased depending on the depth of the ocean: 5 times longer than at the surface for the depths from 1000 to $2500 \mathrm{~m}, 10$ times for 2500 to $3500 \mathrm{~m}$, and 20 times for 3500 to $5500 \mathrm{~m}$. Therefore, the length of the model run was equivalent to, for example, 4000 years for the very deep ocean. While most of the tracers came sufficiently close to equilibrium, the model run was not long enough for ${ }^{14} \mathrm{C}$, which has the longer timescale of radioactive decay, and thus, we do not discuss ${ }^{14} \mathrm{C}$-related results in this study. By using the same acceleration method in all CESM experiments of this study, we assumed that the influence of the model bias due to the acceleration (Danabasoglu, 2004) was mitigated as long as the differences among experiments were discussed. For this CESM spin-up, MEDUSA was not coupled but the original empirical particle-dissolution treatment of the BEC model was used instead. After the CESM spinup, MEDUSA was initialized with a nominal uniform composition of the sediment-core-layer stack and pore water, and spun up for $10^{5}$ years driven by the boundary conditions (i.e. solid-particle fluxes and bottom-water chemical composition in the deepest grid cells of POP2) derived from the spun-up CESM model state.

Following the spin-up sequence, we made two experiments. The first was a sequentially coupled CESMMEDUSA run for another 100 surface years with the same acceleration method for the deep ocean as described above
(EXCPL). The second one was also run for 100 surface years but as a continuation of the "uncoupled" CESM spin-up run (EXORG). The latter experiment was done to examine the effect of the coupling of the process-based sediment model at millennial timescales. Again, it was not long enough for ${ }^{14} \mathrm{C}$ to achieve reasonable steadiness. Both EXCPL and EXORG are designed as an "open" system. Both experiments have a common riverine-inflow field corresponding to the modern river nutrient exports based on Seitzinger et al. (2010) and Mayorga et al. (2010). On the other hand, the net flux of matter through the lower boundary of the ocean domain is calculated by MEDUSA in EXCPL and by the parameterized burial treatment of BEC in EXORG.

In EXCPL, the two models communicated with each other 10 times during the 100 years; that is, the coupling interval was 10 surface years for CESM, which was equivalent to 200 years for the deepest ocean domain (i.e. deeper than $3500 \mathrm{~m}$ ). At the end of each 10-surface-year CESM simulation, the annual mean values of the necessary variables from the last surface year were passed to MEDUSA. We ran MEDUSA for 200 years each time with a 10-year time step (see also the Supplement), and the model output at the last time step was used as input to CESM. Giving priority to the deepest ocean domain that occupies as much as $\sim 70 \%$ of total ocean-floor area, we set the length of one MEDUSA run to 200 years, which is in line with the length of the CESM integration for the deepest ocean domain.

Model performance was assessed by comparing the results to several observation-based datasets. The most straightforward benchmark quantities in the context of model-data comparison relevant for this study are the weight fractions of the solid components in the upper sediment. Here, we focus on the surface sediment calcite, opal, and organic carbon (OC) for which Seiter et al. (2004) provide appropriate global gridded maps. Another important parameter is the degree of saturation of seawater with respect to calcite defined by

$\Omega=\frac{\left[\mathrm{Ca}^{2+}\right]\left[\mathrm{CO}_{3}^{2-}\right]}{K_{\text {calc }}}$,

where $K_{\text {calc }}$ denotes the solubility product of calcite. $\Omega>1$ in waters that are supersaturated with respect to calcite; $\Omega<$ 1 in waters that are undersaturated. We use the global map of Dunne et al. (2012) as a target dataset for the seafloor calcite saturation state derived in our coupled model.

\section{Results}

\subsection{Performance of the coupled model}

First, we evaluate the performance of the ocean component of the coupled model based on the average over the last CESM run (i.e. 10 surface years) in EXCPL. The maximum transport of the Atlantic meridional overturning circulation (AMOC) is $16.6 \mathrm{~Sv}\left(1 \mathrm{~Sv}=10^{6} \mathrm{~m}^{3} \mathrm{~s}^{-1}\right)$, and the volume 
transport at $26.5^{\circ} \mathrm{N}\left(20^{\circ} \mathrm{S}\right)$ is $13.9 \mathrm{~Sv}(12.5 \mathrm{~Sv})$, showing that the physical ocean state is reasonably consistent with the estimates of the modern time-mean values given by several data assimilation studies (Stammer et al., 2016). Given the physical ocean state, the BEC model is able to reproduce the observation-based estimates of various global-scale biogeochemical quantities that are relevant to this study such as the global export rates of $\mathrm{POC}$ and $\mathrm{CaCO}_{3}$, and their deposition rate at the ocean floor (Table 1).

To evaluate the model performance of the sediment part in the coupled model, we diagnostically obtained the weight fraction of solid components in the upper sediment from the outputs of MEDUSA. The weight fraction for calcite (Fig. 2) is of special interest considering that it is closely connected to the atmospheric $\mathrm{CO}_{2}$ level variations at the glacialinterglacial timescale (e.g. Archer et al., 2000; Brovkin et al., 2007, 2012; Munhoven, 2007). The global mean weight fraction of calcite is $21 \%$ at the last time step of the last MEDUSA run in EXCPL and $38 \%$ for the observation-based global map (Seiter et al., 2004). Thus, the coupled model underestimates the fraction of calcite preserved in the upper sediments, which could be partly because the global supply of calcite to the ocean floor itself is somewhat underestimated (Table 1).

We also analysed the model performance in seven geographical regions (Fig. 2d). In five regions, the magnitudes of the differences in the region-mean calcite weight fractions between EXCPL and the observation-based data are smaller than 0.15. In particular, small model-data mismatches are realized in the North Atlantic, the western Pacific, and the Southern Ocean.

In the North Atlantic, the spatial distributions are not consistent, although the modelled region-mean weight fraction is comparable to that derived from the data. For example, the calcite weight fraction is significantly higher in the western North Atlantic in the model results than in the observationbased data by Seiter et al. (2004). A more recent observationbased dataset (Dutkiewicz et al., 2015), however, indicates that the major lithology of ocean-floor sediments is calcareous matter in the western North Atlantic, the Caribbean Sea, and the Gulf of Mexico. Although we cannot make a quantitative comparison between the newer dataset and our model result because Dutkiewicz et al. (2015) does not provide the weight fraction, the model result seems to be consistent with the recent data in those regions. The discrepancy between the two observational datasets makes the interpretation of the model results in the western North Atlantic elusive. On the other hand, it is also presumable that the model overestimates the supply of calcite to the sediment in the midwest area of the North Atlantic because the modelled phosphate concentration in the surface water is higher than observed in that region (not shown), which would lead to an overestimation of biological production.

Noticeable discrepancies in the region-mean calcite weight fractions are found in the eastern South Pacific and
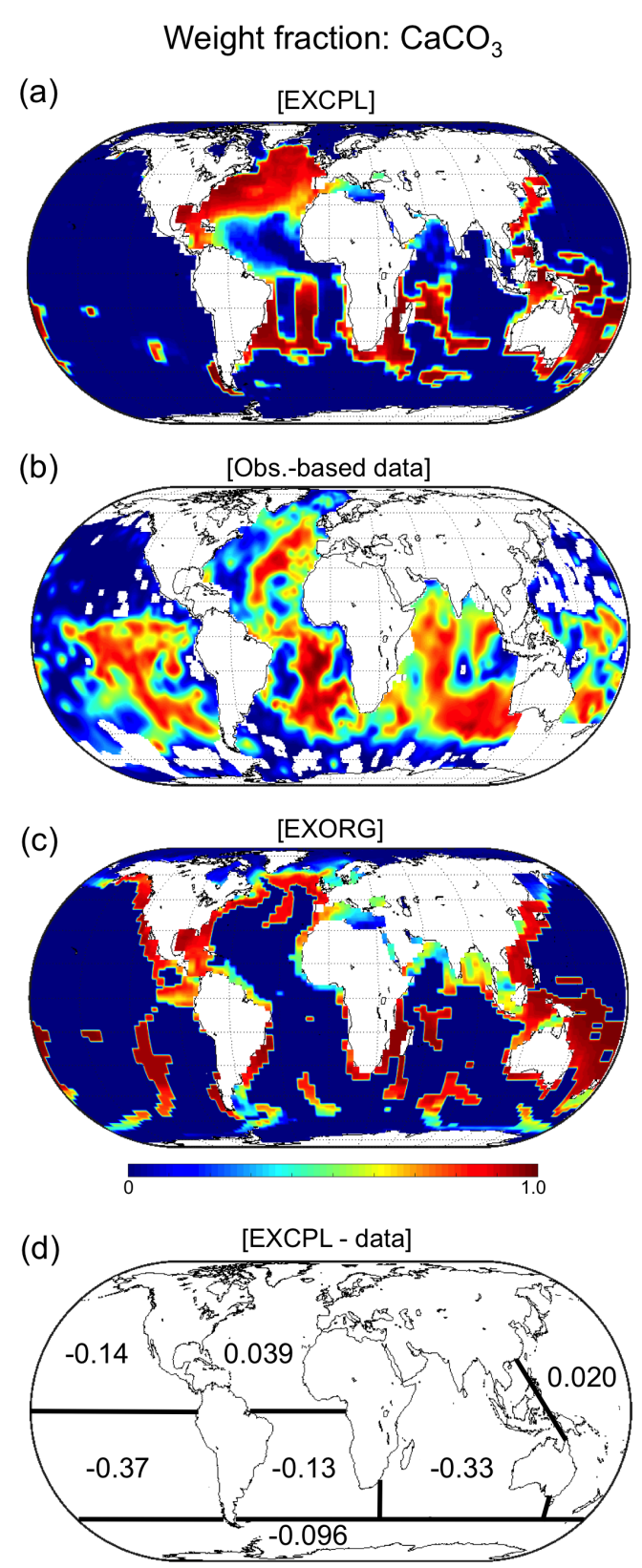

Figure 2. The weight fraction of the $\mathrm{CaCO}_{3}$ component in the upper sediments: (a) EXCPL, (b) the gridded map derived from observations (Seiter et al., 2004), and (c) EXORG. For EXCPL, the model state at the last time step of the last MEDUSA run is shown. The characteristic timescale of sediment-stack evolution is much longer than 10 years, so that the weight fraction at the last time step sufficiently represents the model state. For EXORG, we estimated the weight fraction by taking the ratio of the amount of solid matter that was excluded from the model ocean domain at the ocean floor based on the time averages over the last 10 surface years of the CESM run. (d) The breakdown of the EXCPL-data discrepancies into seven regions. The differences of the regional mean values for each domain are shown (EXCPL minus data). 
Table 1. Comparison of globally integrated biogeochemical quantities of this study with previous estimates available from observations. For EXCPL, fluxes to allow consistent comparison with the previous estimates were calculated from the time averages over the last CESM run (10 surface years).

\begin{tabular}{|c|c|c|}
\hline & This study (EXCPL) & Previous estimates \\
\hline \multicolumn{3}{|l|}{ Atmospheric $p \mathrm{CO}_{2}(\mathrm{ppm})$} \\
\hline Global mean & 276.9 & 285.2 (Etheridge et al., 1996) \\
\hline \multicolumn{3}{|l|}{ 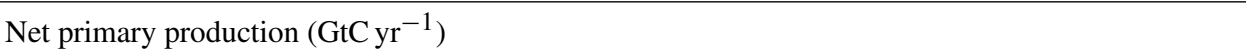 } \\
\hline & 59.4 & $\begin{array}{l}48.5 \text { (Field et al., 1998) } \\
49-60 \text { (Carr et al., 2006) } \\
54 \text { (Dunne et al., 2007) } \\
48.2 \text { (Laws et al., 2011) } \\
55 \text { (Ma et al., 2014) }\end{array}$ \\
\hline \multicolumn{3}{|l|}{$\mathrm{POC}\left(\mathrm{Gt} \mathrm{yr}^{-1}\right)$} \\
\hline Export at $100 \mathrm{~m}$ & 7.2 & $\begin{array}{l}\text { 9.6 } \pm 3.6 \text { (Dunne et al., 2007) } \\
\text { 9.2-13.2 (Laws et al., 2011) } \\
4.0 \text { (Henson et al., 2012) } \\
\text { 5.7 (Siegel et al., 2014) }\end{array}$ \\
\hline $\begin{array}{l}\text { Flux to ocean floor below } 1000 \mathrm{~m} \\
\text { between } 60^{\circ} \mathrm{N} \text { and } 60^{\circ} \mathrm{S}\end{array}$ & 0.33 & 0.13 (Dunne et al., 2007) \\
\hline \multicolumn{3}{|l|}{$\mathrm{CaCO}_{3}\left(\mathrm{GtC} \mathrm{yr}^{-1}\right)$} \\
\hline Export at $100 \mathrm{~m}$ & 0.95 & $\begin{array}{l}1.1 \pm 0.3 \text { (Lee, 2001) } \\
0.5-4.7 \text { (Berelson et al., 2007) } \\
0.52 \pm 0.15 \text { (Dunne et al., 2007) } \\
0.72-1.05 \text { (Battaglia et al., 2016) }\end{array}$ \\
\hline Flux to ocean floor below $2000 \mathrm{~m}$ & 0.32 & $0.5 \pm 0.3$ (Berelson et al., 2007) \\
\hline \multicolumn{3}{|l|}{ Opal (Tmol yr $\left.{ }^{-1}\right)$} \\
\hline Export at $100 \mathrm{~m}$ & 88.6 & $\begin{array}{l}120 \text { (Tréguer et al., 1995) } \\
70-100 \text { (Gnanadesikan, 1999) } \\
101 \pm 35 \text { (Dunne et al., 2007) } \\
105 \text { (Tréguer and De La Rocha, 2013) }\end{array}$ \\
\hline Flux to ocean floor & 46.4 & $\begin{array}{l}29.1 \text { (Tréguer et al., 1995) } \\
22.1 \text { (Dunne et al., 2007) } \\
78.8 \text { (Tréguer and De La Rocha, 2013) }\end{array}$ \\
\hline
\end{tabular}

in the Indian Ocean. The Pacific anomaly, which shows a too-low modelled calcite weight fraction, is caused by toocorrosive bottom water. The $\Omega$ of the bottom water in that area is lower in the model results than that in the observationbased data (Fig. 3). The strongly undersaturated water having too-low $\mathrm{pH}$ is caused by the remineralization of an anomalous amount of $\mathrm{OM}$, as indicated by the too-high concentration of phosphate in the deep water in this region (Fig. 4a-c) and by too much consumption of oxygen as well (Fig. 4df), which are consistent with the too-high weight fraction of OC in the eastern equatorial South Pacific (Fig. 5a). A similar explanation is applicable to the Indian Ocean where the modelled calcite weight fraction is also lower than that in the observation-based estimates; the model similarly under- estimates $\Omega$ in that region, which affects the preservation of calcite in the sediments.

The simulated weight-fraction fields for OC and opal show that they are minor components in general compared to calcite, and that is consistent with the observation-based data (Figs. 5 and 6). In some regions, for example, in the eastern South Pacific (around $25^{\circ} \mathrm{S}, 110^{\circ} \mathrm{W}$ ), the simulated OC weight fraction is lower than the observed OC fraction. This correlates with the underestimation of the calcite weight fraction (Fig. 2), which implies that less calcite burial may cause a slower sedimentation rate, leading to a longer exposure of OC to the pore water in the upper sediment and thus facilitating its respiration. Although some more model-data mismatches are visible mainly in coastal areas (for OC) and in 

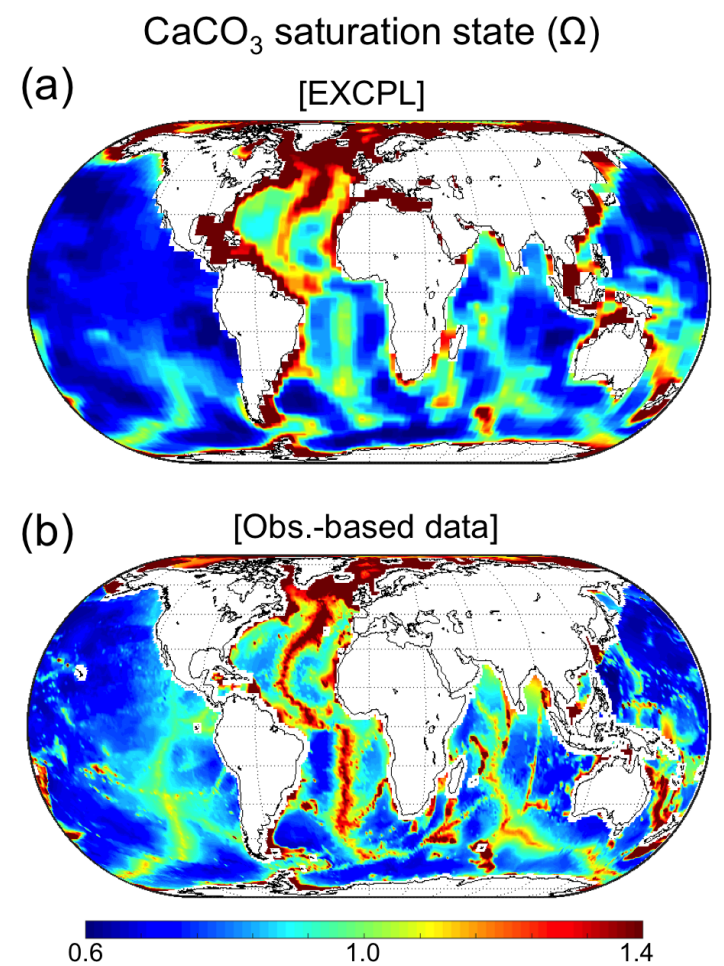

Figure 3. Saturation state for calcite of the bottom seawater $(\Omega)$. (a) The model state in the deepest grid cells averaged over the last CESM run (10 surface years) in EXCPL and (b) observation-based estimates by Dunne et al. (2012).

the Southern Ocean (for opal), the performance of the coupled model is remarkably better than that of the uncoupled model regarding the weight fraction of the two components (see also Sect. 3.2).

While the model performance with regard to the calcite weight fraction may be improved to some extent by changing the model parameters of MEDUSA that govern the calcite dissolution rate, we keep the default parameter values for EXCPL in this study, which helps to assess the model performance in a standard setting. We judge the general model performance including the reproduction of the approximate pattern of global solid weight-fraction fields to be adequate at this stage, at least for the following analyses and discussion that does not require an accurate reproduction of the observations.

\subsection{Comparison with the uncoupled model}

Although the development of the coupled model in this study has been motivated by the aim of simulating the glacialinterglacial variations including the marine carbon cycle as an open system (Sigman and Boyle, 2000), we find that the sediment-model coupling has non-negligible influences on ocean biogeochemistry even in millennial-timescale simulations. The most prominent effect is found in the composition of the upper sediment. For EXORG, we estimated the weight fraction of the solid components by taking the ratio of the amounts of each component and total solid matter that was excluded from the model ocean domain at the ocean floor, because the uncoupled CESM did not have explicit sediment stacks.

The weight-fraction distribution for EXORG shows that the uncoupled model behaves differently. The rough feature of the global distribution of the calcite weight fraction in EXORG is similar to that in EXCPL or the observation-based data because of the appropriate depth of the prescribed lysocline (Fig. 2c). However, EXORG underestimates the fraction mainly in the Atlantic, presumably because the spatially constant lysocline is at shallower depths than observed in that area. On the other hand, the weight-fraction distributions for OC and opal show obvious discrepancies between the model results and the data. The weight fraction of OC in EXORG is unreasonably higher than that in the data in most regions of the global ocean and does not even approximately reproduce the observed spatial pattern (Fig. 5c). This is the case also for the opal weight fraction. The opal fraction in EXORG clearly deviates from the data, although it implies a higher fraction in the Southern Ocean and the eastern equatorial Pacific as suggested by the observations (Fig. 6c). Such large model errors would complicate the model-data comparison for the upper sediment composition. Therefore, the coupling of a more reliable sediment model like MEDUSA to CESM is essential for a straightforward comparison between model results and observations.

The noticeable differences in the weight fractions of OC and opal between EXCPL and EXORG are mostly caused by the different degrees of preservation of those two species in the upper sediment. Burial ratios (the ratios of burial amount to the flux to the ocean bottom) of OM and opal calculated by MEDUSA in EXCPL are remarkably different from those given by the highly simplified parameterization in the original CESM (Fig. 7). In particular, the ratios in EXCPL are significantly lower in low-flux locations, which means that the difference will be larger in the open ocean. Depending on whether OM or opal forms the major part of the total particulate flux (e.g. opal in the Southern Ocean), the difference in burial ratios will lead to substantial discrepancies in terms of the weight fraction.

As to the ocean state, EXORG has large-scale properties very similar to those for EXCPL; that is to say, in EXORG (EXCPL), the maximum strength of AMOC is $16.7 \mathrm{~Sv}$ $(16.6 \mathrm{~Sv})$, the global export production is $8.1 \mathrm{GtC} \mathrm{yr}^{-1}$ $\left(8.1 \mathrm{GtC} \mathrm{yr}^{-1}\right)$, and the global export rain ratio of $\mathrm{CaCO}_{3}$ is 0.13 (0.13), which suggests that the different treatment of the sedimentary processes does not have a remarkable effect on the overall physical and biogeochemical states of the ocean through the $p \mathrm{CO}_{2}$ and dynamics of the atmosphere in our simulations. The two experiments are also comparable in terms of other globally integrated quantities such as the deposition fluxes of particulate matter and the total inventories of biogeochemical tracers (Tables 2 and 3). This is 

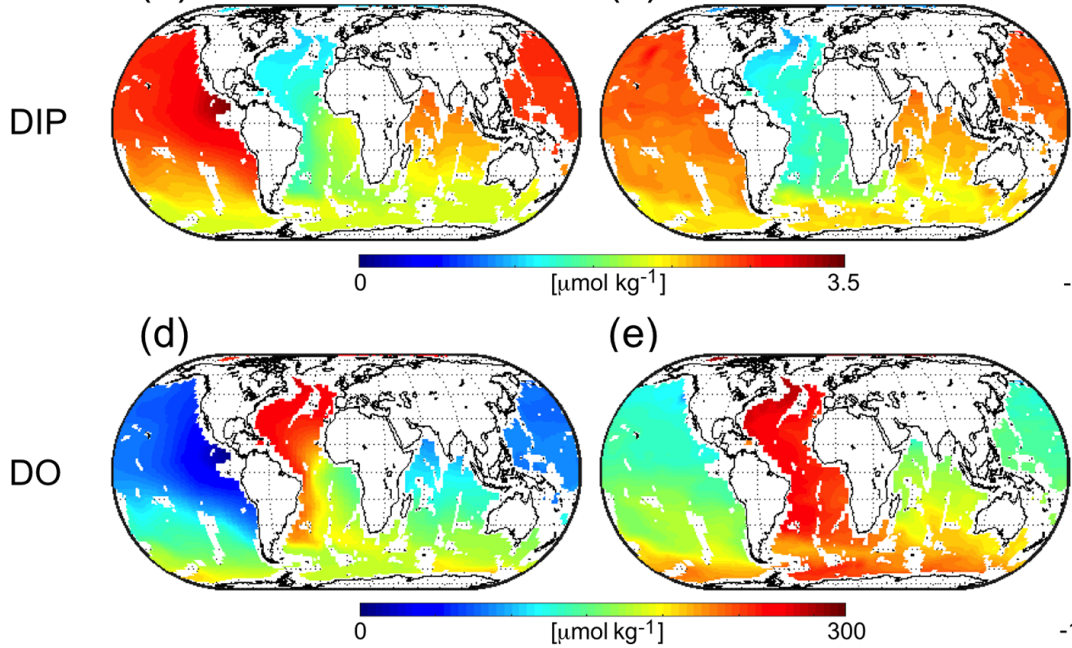

(g)

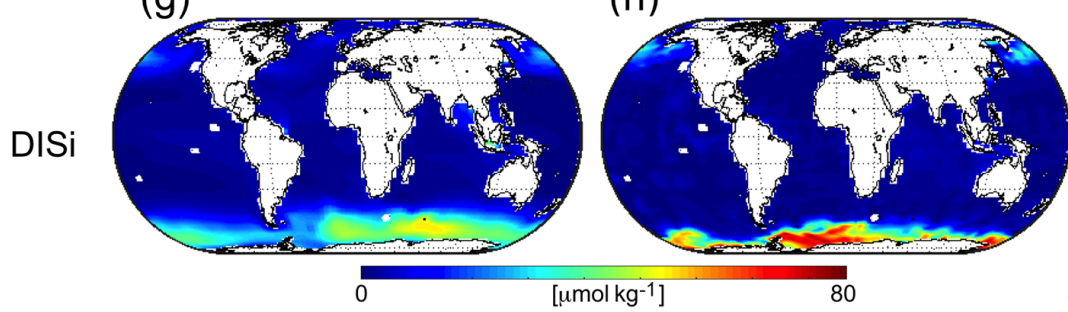

\section{[EXCPL]}

(a)

(d)

[Obs.-based data]

(b)

(e)

DO (h)

(i)
[EXCPL - data]

(c)

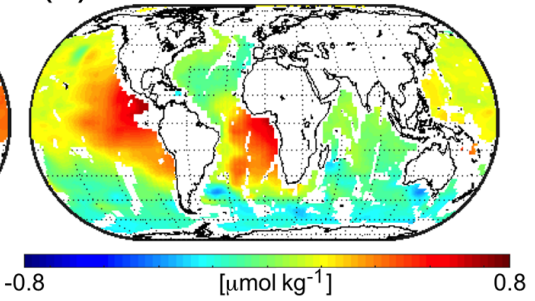

(f)

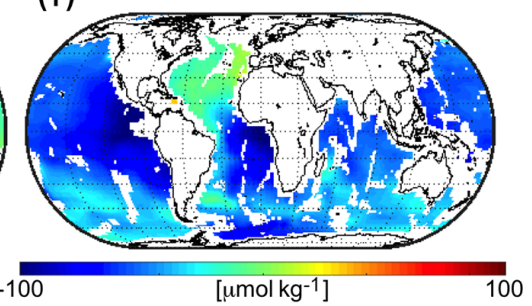

(i)

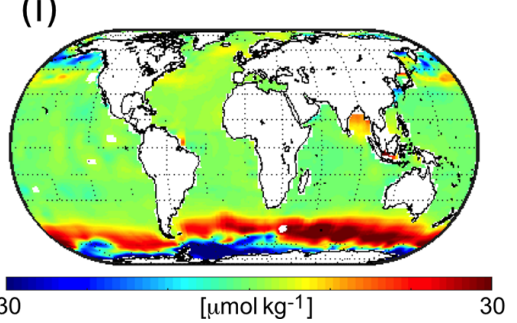

Figure 4. Distribution of marine biogeochemical tracers: (a-c) dissolved inorganic phosphate at the depth of $3000 \mathrm{~m}$, (d-f) dissolved oxygen at $3000 \mathrm{~m}$, and (g-i) dissolved inorganic silicate at $10 \mathrm{~m}$. The left column shows the time averages over the last CESM run (10 surface years) in EXCPL, the centre shows observation-based data (GLODAPv2; Lauvset et al., 2016), and the right column shows the anomaly given by model results minus the data.

Table 2. Globally integrated annual mean deposition flux of particulate matter to the sediment and their burial flux (in parentheses) at the end of EXCPL and EXORG.

\begin{tabular}{lrr}
\hline & EXCPL & EXORG \\
\hline POC $\left(\mathrm{GtC} \mathrm{yr}^{-1}\right)$ & $\begin{array}{r}0.57 \\
(0.091)\end{array}$ & $\begin{array}{r}0.51 \\
(0.12)\end{array}$ \\
\hline $\mathrm{CaCO}_{3}\left(\mathrm{GtC} \mathrm{yr}^{-1}\right)$ & 0.39 & 0.38 \\
& $(0.082)$ & $(0.14)$ \\
\hline Opal $\left(\mathrm{Tmol} \mathrm{yr}^{-1}\right)$ & 46 & 45 \\
& $(0.72)$ & $(3.4)$ \\
\hline
\end{tabular}

reasonable because the timescale at which the sedimentary processes alter the chemical state of the global ocean is very long $\left(\mathrm{O}\left(10^{5}\right)\right.$ years $)$ considering the slow turnover rate estimated from the size of the ocean carbon reservoir and the flux exchanged with the sediments (Ciais et al., 2013).

However, the effect of the interactive coupling of MEDUSA on the local bottom-water chemistry is not negligible. The difference in $\delta^{13} \mathrm{C}$ of DIC $\left(\Delta \delta^{13} \mathrm{C}_{\mathrm{DIC}}\right.$; hereafter,
Table 3. Total inventories in the global ocean of DIC, ALK, and $\mathrm{PO}_{4}$ in EXCPL and EXORG. Values averaged over the last CESM run (10 surface years) are shown.

\begin{tabular}{lrr}
\hline & EXCPL & EXORG \\
\hline DIC (GtC) & $3.660 \times 10^{4}$ & $3.657 \times 10^{4}$ \\
\hline ALK (Peq) & $3.201 \times 10^{3}$ & $3.201 \times 10^{3}$ \\
\hline $\mathrm{PO}_{4}(\mathrm{Pmol})$ & 2.948 & 2.923 \\
\hline
\end{tabular}

$\Delta$ indicates the difference given by EXCPL minus EXORG) in the deepest grid cells of the ocean model is $\sim 0.2 \%$ or larger in a substantial number of areas (Fig. 8a). Some of these areas correlate closely with the regions of high POC flux to the sediment (Fig. 9) or high POC weight fraction (Fig. 5a): along the east coast of the equatorial Pacific, along the west coast of the Pacific, and in the Arctic and Hudson Bay, for example. These regions (except for the eastern equatorial Pacific) have negative $\Delta \delta^{13} \mathrm{C}_{\text {DIC }}$. The low $\delta^{13} \mathrm{C}_{\mathrm{DIC}}$ values suggest that there is a larger amount of supply of "lighter" carbon from the sediment to the seawater in such regions, 


\section{Weight fraction: org. C}

(a)

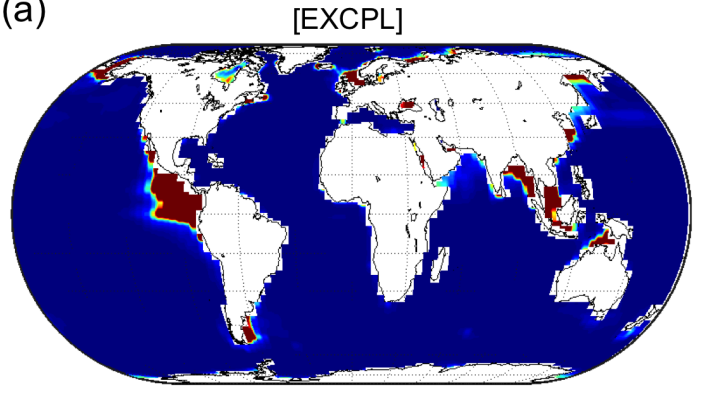

(b)

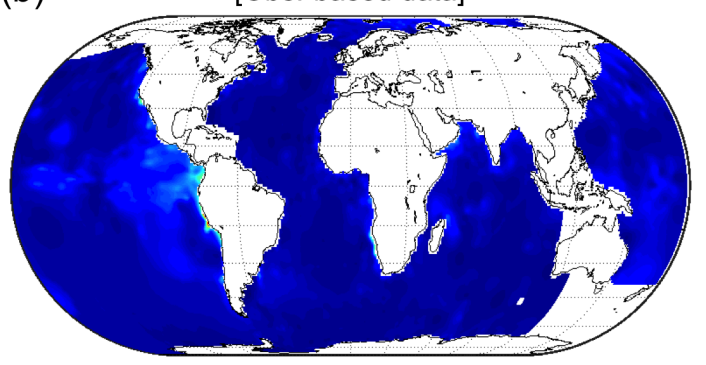

(c)

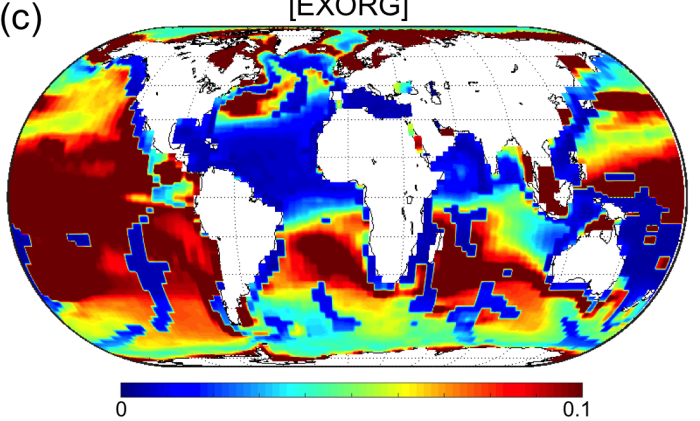

Figure 5. The weight fraction of the organic-carbon component in the upper sediments: (a) EXCPL, (b) the gridded map derived from observations (Seiter et al., 2004), and (c) EXORG. For EXCPL, the model state at the last time step of the last MEDUSA run is shown.

which results from the remineralization of a larger amount of OM. This is supported by the large flux of oxygen from the seawater to the sediment in the same regions (Fig. 10a), that could have been caused by a large vertical gradient of oxygen concentration, and is supported by the large DIC flux from the sediment to the seawater as well (Fig. 11). As a result, the distribution of $\Delta \mathrm{O}_{2}$ and $\triangle \mathrm{DIC}$ has a very similar spatial pattern to that of $\Delta \delta^{13} \mathrm{C}_{\text {DIC }}$ (Fig. 8b, c). This scenario is also consistent with the $\Delta \mathrm{PO}_{4}$ distribution (Fig. 8d), which is anti-correlated with that of $\Delta \delta^{13} \mathrm{C}_{\text {DIC }}$.

A similar explanation, however, is not applicable to the eastern equatorial Pacific having positive $\Delta \delta^{13} \mathrm{C}_{\text {DIC. The }}$ seawater with larger $\delta^{13} \mathrm{C}_{\mathrm{DIC}}$ values suggests that there is a smaller amount of supply of lighter carbon in spite of a large flux of POM to the sediment. In that region, the amount of (oxic) remineralization in the upper sediment is limited

\section{Weight fraction: opal}
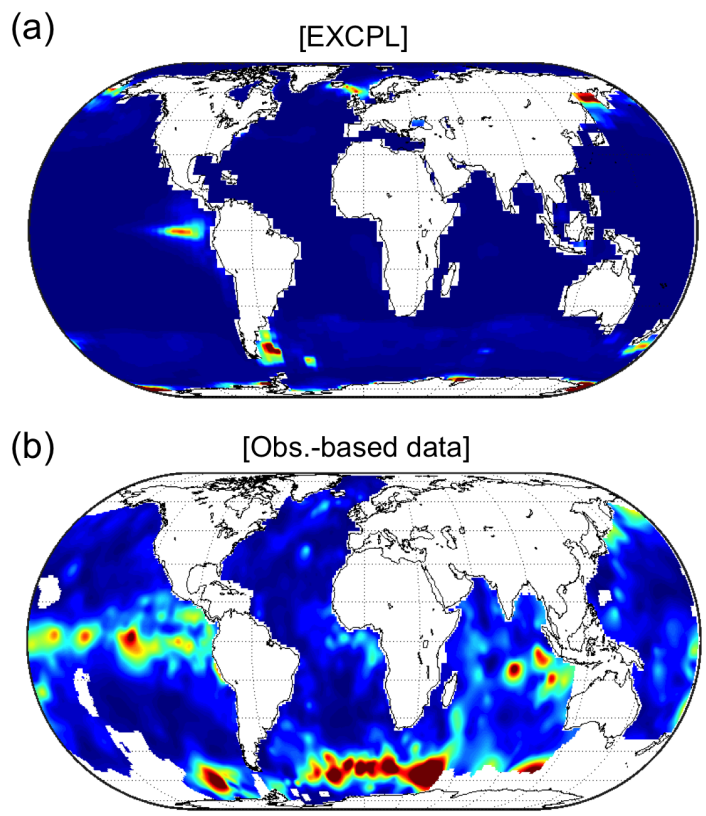

(c)

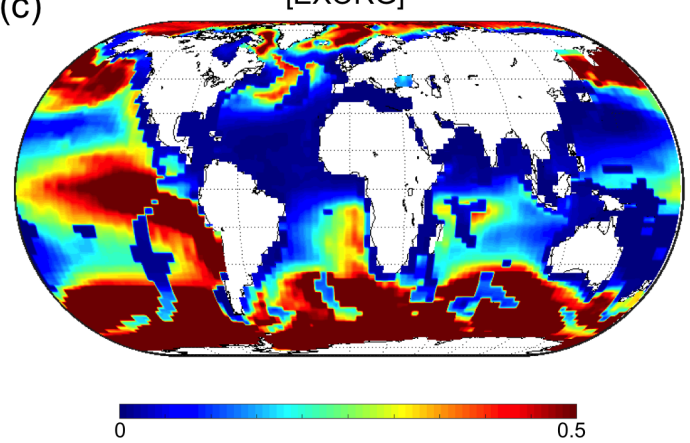

Figure 6. The weight fraction of the opal component in the upper sediments: (a) EXCPL, (b) the gridded map derived from observations (Seiter et al., 2004), and (c) EXORG. For EXCPL, the model state at the last time step of the last MEDUSA run is shown.

by the reduced oxygen supply from the seawater (Fig. 10a) due to the oxygen-depleted deep water (Fig. 4d), although the model seems to underestimate the amount of oxygen available there as seen in comparisons with the corresponding observation-based fields (Figs. 10b and 4f). The limited amount of remineralization in the model result is also consistent with the very low DIC flux from the sediment to the ocean (Fig. 11). That leads to more burial of lighter carbon (i.e. less supply of lighter carbon to the seawater), which results in the heavier $\delta^{13} \mathrm{C}_{\mathrm{DIC}}$ in the bottom water.

On the other hand, the remarkable dipole structure of the $\Delta \delta^{13} \mathrm{C}_{\text {DIC }}$ field in the North Atlantic is not well correlated with the high-OM-flux regions (Fig. 9). Instead, it results from water mass displacement caused by ocean circulation changes rather than from the direct influence of the sediment, which shows that, although the overall sediment feedback on 
(a)

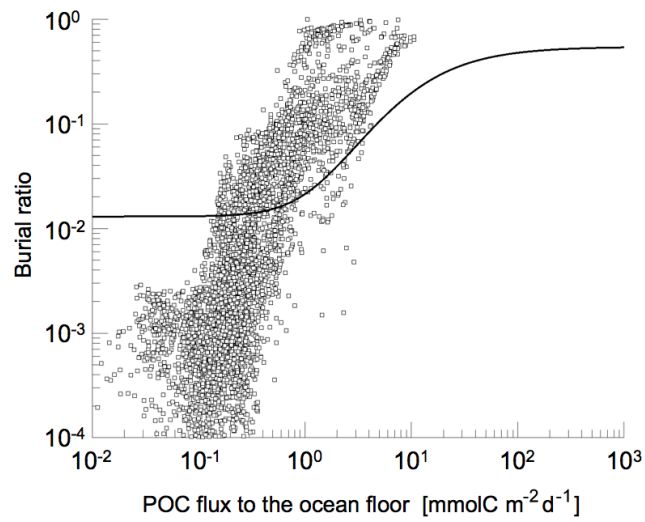

(b)

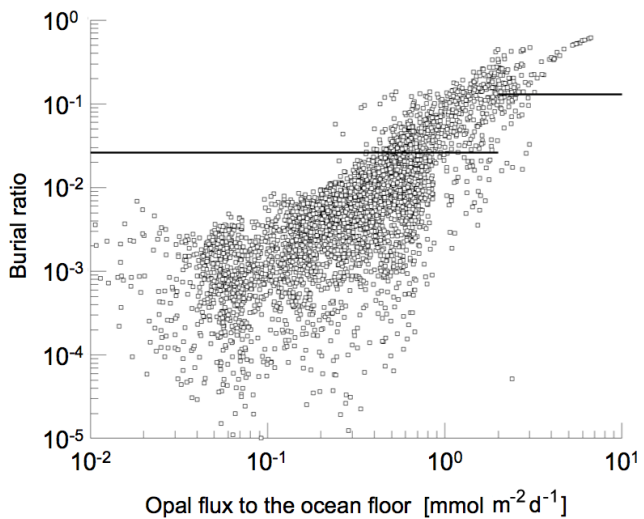

Figure 7. Sediment burial ratios versus the particulate flux to the ocean floor for (a) OC and (b) opal. The dots show the ratio at each grid cell obtained in the last MEDUSA run for EXCPL. The solid lines indicate those given by the parameterized models in the original CESM (BEC) based on Dunne et al. (2007) for OC and Ragueneau et al. (2000) for opal.

\section{$[E X C P L-E X O R G]$}

(a)

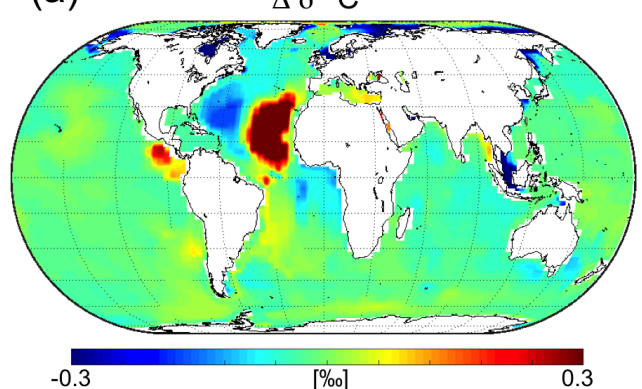

(c)

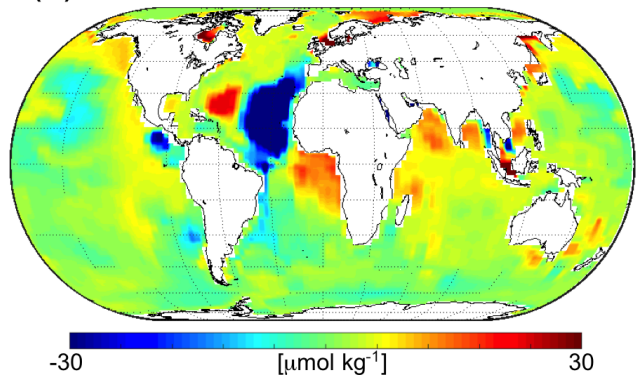

(b)

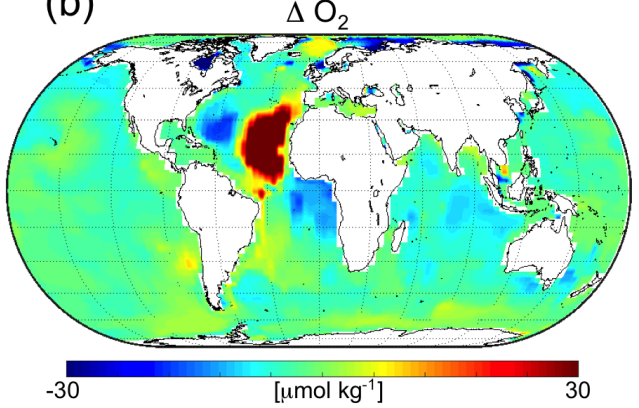

(d)

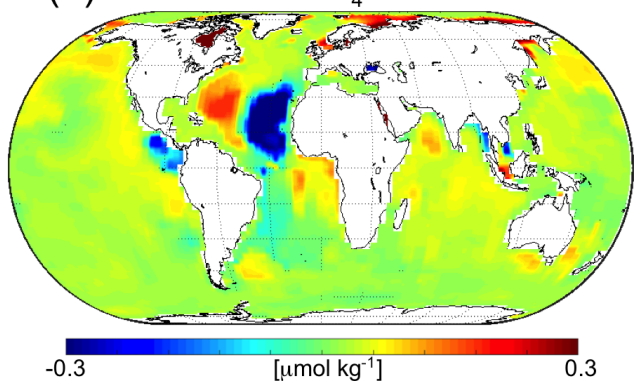

Figure 8. The difference in the chemical composition of the deepest grid cells between EXCPL and EXORG that was obtained from the time averages over the last 10 surface years of the CESM run in each experiment. $\Delta$ indicates an anomaly given by EXCPL minus EXORG.

the physical ocean states is subtle as mentioned above, some local effects are clearly visible. The negative anomaly of $\delta^{13} \mathrm{C}_{\mathrm{DIC}}$ in the western North Atlantic is caused by the difference in AMOC magnitude. In EXCPL, there is a somewhat weaker penetration of northern source water into the deep low-latitude to midlatitude Atlantic than in EXORG (not shown). The weaker penetration means that less ${ }^{13} \mathrm{C}$-rich (or nutrient-depleted) surface water is transported into the deep ocean, which results in the negative $\Delta \delta^{13} \mathrm{C}_{\mathrm{DIC}}$. The positive anomaly in the eastern North Atlantic is caused by the difference in the strength of the northward current along the African continent in the deep ocean. The current is weaker in EXCPL so that it conveys a smaller amount of ${ }^{13} \mathrm{C}$-depleted (or nutrient-rich) water to the North Atlantic. As a result, the bottom water in EXCPL shows heavier $\delta^{13} \mathrm{C}_{\text {DIC }}$ values in the eastern part of the low-latitude North Atlantic and lighter $\delta^{13} \mathrm{C}_{\text {DIC }}$ values in the South Atlantic along the African con- 
POC flux at the top of sediment

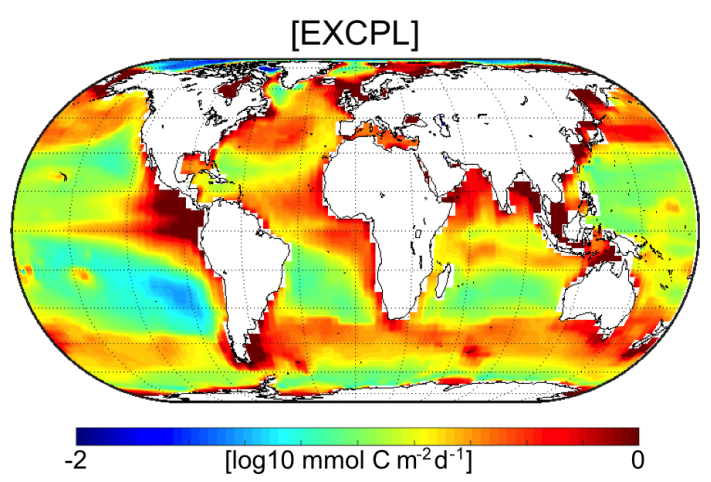

Figure 9. The flux of particulate organic carbon at the top of the sediment. The time averages over the last CESM run (10 surface years) in EXCPL are shown. The same scale as that in Fig. 5a of Dunne et al. (2007) is used to facilitate comparison.

\section{$\mathrm{O}_{2}$ flux at the top of sediment}

(a)

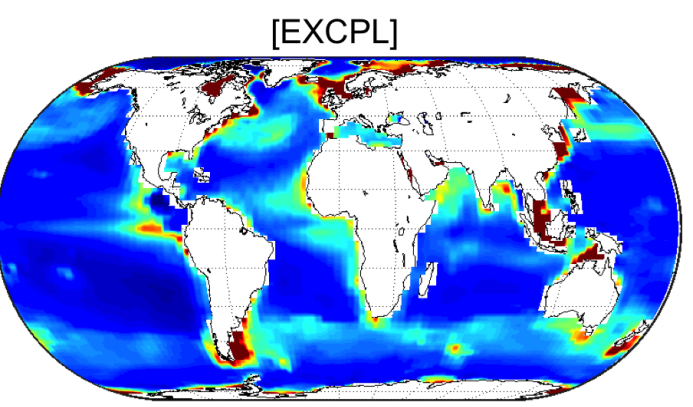

(b)

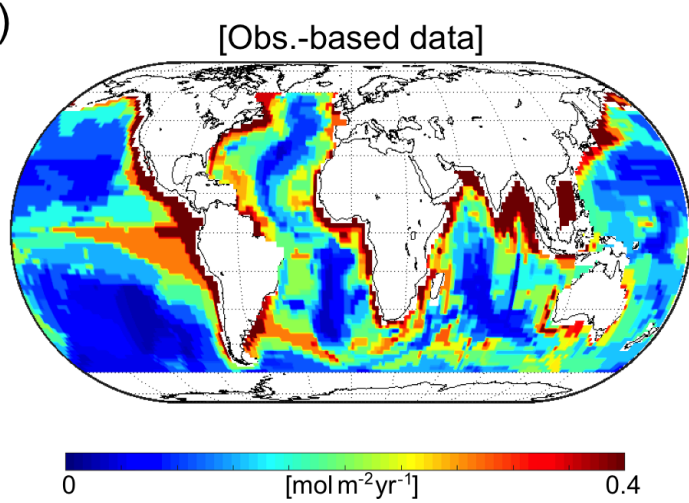

Figure 10. Oxygen fluxes at the water-sediment boundary (a) at the last time step of the last MEDUSA run in EXCPL and (b) observation-based estimate (Jahnke, 1996). The sign is downward positive; that is to say, positive values correspond to fluxes from ocean to sediments.

\section{DIC flux at the top of sediment}

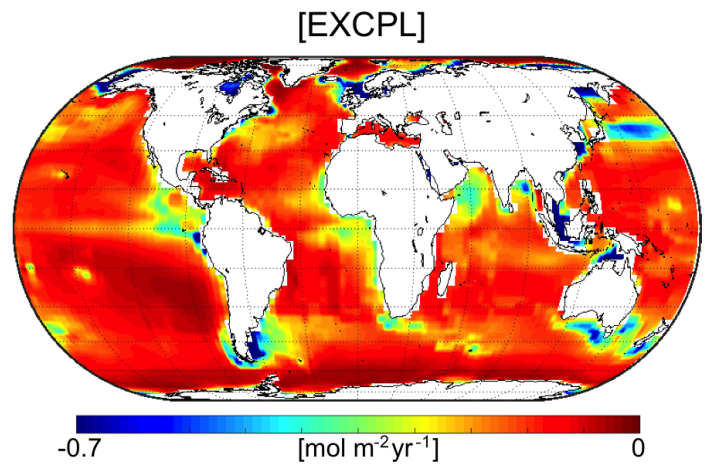

Figure 11. DIC fluxes at the water-sediment boundary at the last time step of the last MEDUSA run in EXCPL. The sign is downward positive; that is to say, positive values correspond to fluxes from ocean to sediments.

tinent. This mechanism also explains well the anomalies of the other tracers in the same regions (Fig. 8b-d).

\section{Discussion and outlook}

The most straightforward advantages of coupling CESM to MEDUSA are two-fold. First, the sediment model offers the explicit modelling of chemical and physical processes in the upper sediments, and second, modelled sediment stacks provided the climate model with sedimentary "archives". In future applications, those two advantages will facilitate a direct comparison between the climate model and (paleoceanographic) data taken from sediments, which will provide a valuable constraint on the model from a paleoclimatological/paleoceanographic viewpoint. Otherwise, one would need to translate records obtained from sediments in an empirical way to corresponding variables of the ocean model, which would introduce an additional source of uncertainty to the model-data comparison. Those advantages are clearly demonstrated in the comparison of the solid weight-fraction distribution among EXCPL, EXORG, and the observation-based data. Additionally, the state of the upper sediments at a certain time has a vertical structure reflecting the "memory" of past states because the vertical mixing of the solid phase occurs by means of bioturbation. MEDUSA has an adequate model structure including interphase biodiffusion (Munhoven, 2007) to simulate such a hysteresis effect, thereby a modelled time series of sediment properties will be available as well.

In addition to the direct advantages, the sediment model will influence the simulated ocean biogeochemistry by providing more realistic boundary conditions. The early diagenetic processes in the upper sediments produce the chemical fluxes to the ocean and hence directly affect the chemical composition of the bottom water. The results of this study 
suggest that the feedback from the upper sediments would have substantial impacts on the bottom-water chemistry even at millennial timescales. Consequently, it would be worth considering carefully how to model the sediment feedback in an ocean or climate model, and a prognostic sediment model that simulates the early diagenetic processes explicitly will have an advantage, especially if it is used for a climate simulation covering different climate states and the transitions between them. In this study, the MEDUSA coupling produces $\delta^{13} \mathrm{C}_{\text {DIC }}$ differences of up to $0.2 \%$ compared to the original BEC method through direct influence from the sediment and through feedbacks from the ocean physics leading to the water mass displacement as well. This result indicates that neglecting the sediment processes may cause a large error in the modelled chemical compositions of the bottom water. We emphasize that this error is significant in (paleo-)ocean simulations because its magnitude is close to $10 \%$ of the typical range of $\delta^{13} \mathrm{C}_{\mathrm{DIC}}$ values in the ocean. For example, it is comparable with the prescribed uncertainty for fitting a model to data in a paleo state estimate (Kurahashi-Nakamura et al., 2017) that takes proxy data from benthic foraminifera into account. This will be even more important in the event that the other components of uncertainty have smaller contributions as implied by Breitkreuz et al. (2018).

As a future application of the coupled model, we aim at investigating the role of sedimentary diagenesis in the climate changes at glacial-interglacial timescales. In this context, one of the future tasks will be a simulation of the evolution of the atmospheric carbon dioxide concentration $\left(p \mathrm{CO}_{2}\right)$ as recorded in Antarctic ice cores (Berner et al., 1980; Barnola et al., 1987; Augustin et al., 2004). A simulation of the history of $p \mathrm{CO}_{2}$ at such timescales is one of the crucial challenges of climate science, and it is widely considered that the ocean could have played a key role in the $p \mathrm{CO}_{2}$ variations because of its dominant size as a carbon reservoir (e.g. Sigman and Boyle, 2000; Ciais et al., 2013). The budget of $\mathrm{CaCO}_{3}$ in the global ocean, that is, the balance of the $\mathrm{CaCO}_{3}$ inflow by weathering on land and the outflow by sedimentary burial, would have had a substantial effect on the distribution of total carbon to the ocean and atmosphere, and hence $p \mathrm{CO}_{2}$, by changing the acidity or basicity of the entire ocean (e.g. Archer et al., 2000; Matsumoto et al., 2002; Brovkin et al., 2007; Munhoven, 2007; Chikamoto et al., 2008; Boudreau et al., 2010, 2018). It is highly important, therefore, to properly simulate the preservation or dissolution of $\mathrm{CaCO}_{3}$ in ocean-floor sediments in order to handle the mechanism quantitatively. The relatively good agreement of the calcite weight fraction between EXORG and the observation-based field suggests that calcite preservation depends mainly on water depth and implies that the "fixedlysocline" method might be practical for a given ocean state as long as an appropriate threshold depth can be prescribed. However, generally the depth of lysocline is not constant but depends on the ambient seawater chemistry. This indicates that the fixed depth optimized for one ocean state is not necessarily suitable for another ocean state. Therefore, largescale and long-term climate change studies will certainly require a dynamical sediment diagenesis model. More specifically, MEDUSA will provide CESM with the crucial ability to simulate the feedback between the $\mathrm{CaCO}_{3}$ budget and the global ocean chemistry that is often referred to as carbonate compensation (e.g. Broecker and Peng, 1987; Archer et al., 2000).

We consider that using comprehensive models, given their higher computational cost, for that purpose has at least three advantages over using EMICs. First, EMICs typically use more empirical parameterizations than process-based representations of physical (and other) phenomena in their model components to realize a more efficient computation. For many EMICs, this applies in particular to the atmospheric component. Such model representations cannot properly capture the feedback from variations in model input if it is beyond the range of the underlying empirical relationship. From this viewpoint, comprehensive models would be more advantageous to simulate the response of the atmosphere or the ocean to the variation in the sediment component in a long-term transient "paleo" simulation that explores climate states very different from the present day. Second, the ocean component of some EMICs is of lower dimension (e.g. Ganopolski and Brovkin, 2017) and/or coarser spatial resolution (e.g. Ridgwell, 2007; Norris et al., 2013). Using primitive equations in the atmosphere and ocean combined with a higher spatial resolution is a clear advantage in comparing model results to local observations because it reduces the uncertainty introduced by the mapping, averaging, or interpolation of either model output or data. Third, as an indirect merit, it enables us to evaluate the performance of comprehensive CMIP5-level climate models with respect to additional observational datasets from a new archive (i.e. ocean sediments), which is a significant benefit, considering that the assessment of model performance is a crucial task in the global-climate-projection context (e.g. Flato et al., 2013).

\section{Conclusions}

We coupled a dynamical model of early diagenesis in ocean sediments (MEDUSA) to the ocean component including a biogeochemical module of an advanced comprehensive climate model (CESM1.2). A simulation for the modern climate state demonstrated that the coupled CESM-MEDUSA model is able to approximately simulate the observed global patterns of solid composition in the upper sediments.

The comparison between the coupled and uncoupled models shows that the coupling of MEDUSA only has minor effects on the bulk properties of the global ocean in millennialtimescale climate simulations, as expected from the characteristic timescale of sedimentary processes. This study, however, reveals that the sediment-model coupling is significant in two aspects even at such a timescale. First, the simulated 
sediments provide an additional measure of model performance, and the observation-based global distributions of sediment properties are much better reproduced by CESM coupled to MEDUSA than by the uncoupled CESM. Secondly, some immediate effects of the sediment-model coupling are found in the chemical composition of the bottom water. The difference in the chemical composition of the bottom water between the MEDUSA-coupled model and the uncoupled model is large in the regions of high POC flux to the sediment, which suggests that it would be important to simulate the remineralization of POC in the upper sediments appropriately depending on the bottom-water chemical composition (e.g. oxygen availability). Additionally, the different treatments of the sediment processes can result in some visible displacement of the water masses in the deep ocean, which causes the different distributions of chemical tracers.

The MEDUSA coupling will yield another remarkable advantage over the original model with regard to the $\mathrm{CaCO}_{3}$ dynamics. For long-term climate simulations including the global carbon cycle, the dynamical treatment of the $\mathrm{CaCO}_{3}$ dissolution or preservation in the upper sediments will be essential. We consider the MEDUSA-CESM coupled model as a powerful tool to explore the climate dynamics at glacialinterglacial timescales that will give new insights into the feedback between the sediment processes and the global climate.

Code and data availability. The newly developed model source codes to tailor CESM1.2 and MEDUSA (version 359 or newer) for the coupling and the routines to make input files for either model from output files of the other are available in https://doi.org/10.1594/PANGAEA.905821 (Kurahashi-Nakamura et al., 2019).

Supplement. The supplement related to this article is available online at: https://doi.org/10.5194/gmd-13-825-2020-supplement.

Author contributions. TK developed the model code for the coupling with input from AP and GM. TK and AP designed the experiments, and TK carried them out. TK interpreted and discussed the results with contributions from all co-authors. AP, UM, and MS conceptualized the overarching research goal and acquired the financial support leading to this publication. TK prepared the manuscript with contributions from all co-authors.

Competing interests. The authors declare that they have no conflict of interest.

Acknowledgements. The authors would like to thank the reviewers for their insightful comments and suggestions. This research was funded by the PalMod project (http://www.palmod.de, last ac- cess: 26 February 2020) within the framework of Research for Sustainable Development (FONA; http://fona.de, last access: 26 February 2020) by the German Federal Ministry for Education and Research (BMBF). Guy Munhoven is a research associate with the Belgian Fund for Scientific Research (FNRS).

Financial support. This research has been supported by the German Federal Ministry for Education and Research (BMBF) (grant no. FKZ: 01LP1505D).

The article processing charges for this open-access publication were covered by the University of Bremen.

Review statement. This paper was edited by Paul Halloran and reviewed by two anonymous referees.

\section{References}

Archer, D., Winguth, A., Lea, D., and Mahowald, N.: What caused the glacial/interglacial atmospheric $\mathrm{pCO}_{2}$ cycles?, Rev. Geophys., 38, 159-189, https://doi.org/10.1029/1999RG000066, 2000.

Armstrong, R. A., Lee, C., Hedges, J. I., Honjo, S., and Wakeham, S. G.: A new, mechanistic model for organic carbon fluxes in the ocean based on the quantitative association of POC with ballast minerals, Deep-Sea Res. Pt. II, 49, 219-236, https://doi.org/10.1016/S0967-0645(01)00101-1, 2002.

Augustin, L., Barbante, C., Barnes, P. R. F., Marc Barnola, J., Bigler, M., Castellano, E., Cattani, O., Chappellaz, J., DahlJensen, D., Delmonte, B., Dreyfus, G., Durand, G., Falourd, S., Fischer, H., Flückiger, J., Hansson, M. E., Huybrechts, P., Jugie, G., Johnsen, S. J., Jouzel, J., Kaufmann, P., Kipfstuhl, J., Lambert, F., Lipenkov, V. Y., Littot, G. C., Longinelli, A., Lorrain, R., Maggi, V., Masson-Delmotte, V., Miller, H., Mulvaney, R., Oerlemans, J., Oerter, H., Orombelli, G., Parrenin, F., Peel, D. A., Petit, J.-R., Raynaud, D., Ritz, C., Ruth, U., Schwander, J., Siegenthaler, U., Souchez, R., Stauffer, B., Peder Steffensen, J., Stenni, B., Stocker, T. F., Tabacco, I. E., Udisti, R., van de Wal, R. S. W., van den Broeke, M., Weiss, J., Wilhelms, F., Winther, J.-G., Wolff, E. W., and Zucchelli, M.: Eight glacial cycles from an Antarctic ice core, Nature, 429, 623-628, https://doi.org/10.1038/nature02599, 2004.

Barnola, J. M., Raynaud, D., Lorius, C., and Korotkevich, Y. S.: Vostok ice core provides 160,000-year record of atmospheric $\mathrm{CO}_{2}$, Nature, 329, 408-414, https://doi.org/10.1038/329408a0, 1987.

Battaglia, G., Steinacher, M., and Joos, F.: A probabilistic assessment of calcium carbonate export and dissolution in the modern ocean, Biogeosciences, 13, 2823-2848, https://doi.org/10.5194/bg-13-2823-2016, 2016.

Berelson, W. M., Balch, W. M., Najjar, R., Feely, R. A., Sabine, C., and Lee, K.: Relating estimates of $\mathrm{CaCO}_{3}$ production, export, and dissolution in the water column to measurements of $\mathrm{CaCO}_{3}$ rain into sediment traps and dissolution on the sea floor: A revised global carbonate budget, Global Biogeochem. Cy., 21, GB1024, https://doi.org/10.1029/2006GB002803, 2007. 
Berner, W., Oeschger, H., and Stauffer, B.: Information on the $\mathrm{CO}_{2}$ Cycle from Ice Core Studies, Radiocarbon, 22, 227-235, https://doi.org/10.1017/S0033822200009498, 1980.

Boudreau, B. P., Middelburg, J. J., Hofmann, A. F., and Meysman, F. J. R.: Ongoing transients in carbonate compensation, Global Biogeochem. Cy., 24, GB4010, https://doi.org/10.1029/2009GB003654, 2010.

Boudreau, B. P., Middelburg, J. J., and Luo, Y.: The role of calcification in carbonate compensation, Nat. Geosci., 11, 894-900, https://doi.org/10.1038/s41561-018-0259-5, 2018.

Breitkreuz, C., Paul, A., Kurahashi-Nakamura, T., Losch, M., and Schulz, M.: A dynamical reconstruction of the global monthly-mean oxygen isotopic composition of seawater, J. Geophys. Res.-Oceans, 123, 7206-7219, https://doi.org/10.1029/2018JC014300, 2018.

Broecker, W. S. and Peng, T.-H.: The role of $\mathrm{CaCO}_{3}$ compensation in the glacial to interglacial atmospheric $\mathrm{CO}_{2}$ change, Global Biogeochem. Cy., 1, 15-29, https://doi.org/10.1029/GB001i001p00015, 1987.

Brovkin, V., Ganopolski, A., Archer, D., and Rahmstorf, S.: Lowering of glacial atmospheric $\mathrm{CO}_{2}$ in response to changes in oceanic circulation and marine biogeochemistry, Paleoceanography, 22, PA4202, https://doi.org/10.1029/2006PA001380, 2007.

Brovkin, V., Ganopolski, A., Archer, D., and Munhoven, G.: Glacial $\mathrm{CO}_{2}$ cycle as a succession of key physical and biogeochemical processes, Clim. Past, 8, 251-264, https://doi.org/10.5194/cp-8251-2012, 2012.

Carr, M.-E., Friedrichs, M. A., Schmeltz, M., Aita, M. N., Antoine, D., Arrigo, K. R., Asanuma, I., Aumont, O., Barber, R., Behrenfeld, M., Bidigare, R., Buitenhuis, E. T., Campbell, J., Ciotti, A., Dierssen, H., Dowell, M., Dunne, J., Esaias, W., Gentili, B., Gregg, W., Groom, S., Hoepffner, N., Ishizaka, J., Kameda, T., Quéré, C. L., Lohrenz, S., Marra, J., Mélin, F., Moore, K., Morel, A., Reddy, T. E., Ryan, J., Scardi, M., Smyth, T., Turpie, K., Tilstone, G., Waters, K., and Yamanaka, Y.: A comparison of global estimates of marine primary production from ocean color, Deep-Sea Res. Pt. II, 53, 741-770, https://doi.org/10.1016/j.dsr2.2006.01.028, 2006.

Chikamoto, M. O., Matsumoto, K., and Ridgwell, A.: Response of deep-sea $\mathrm{CaCO}_{3}$ sedimentation to Atlantic meridional overturning circulation shutdown, J. Geophys. Res.-Biogeo., 113, G03017, https://doi.org/10.1029/2007JG000669, 2008.

Ciais, P., Sabine, C., Bala, G., Bopp, L., Brovkin, V., Canadell, J., Chhabra, A., DeFries, R., Galloway, J., Heimann, M., Jones, C., Le Quéré, C., Myneni, R., Piao, S., and Thornton, P.: Carbon and Other Biogeochemical Cycles, in: Climate Change 2013: The Physical Science Basis, Contribution of Working Group I to the Fifth Assessment Report of the Intergovernmental Panel on Climate Change, edited by: Stocker, T., Qin, D., Plattner, G.K., Tignor, M., Allen, S., Boschung, J., Nauels, A., Xia, Y., Bex, V., and Midgley, P., book section 6, Cambridge University Press, Cambridge, United Kingdom and New York, NY, USA, 465570, https://doi.org/10.1017/CBO9781107415324.015, 2013.

Craig, A. P., Vertenstein, M., and Jacob, R.: A new flexible coupler for earth system modeling developed for CCSM4 and CESM1, Int. J. High Perform. C., 26, 31-42, https://doi.org/10.1177/1094342011428141, 2012.

Danabasoglu, G.: A comparison of global ocean general circulation model solutions obtained with synchronous and ac- celerated integration methods, Ocean Model., 7, 323-341, https://doi.org/10.1016/j.ocemod.2003.10.001, 2004.

Danabasoglu, G., McWilliams, J. C., and Large, W. G.: Approach to Equilibrium in Accelerated Global Oceanic Models, J. Climate, 9, 1092-1110, https://doi.org/10.1175/15200442(1996)009<1092:ATEIAG>2.0.CO;2, 1996.

Dunne, J. P., Sarmiento, J. L., and Gnanadesikan, A.: A synthesis of global particle export from the surface ocean and cycling through the ocean interior and on the seafloor, Global Biogeochem. Cy., 21, GB4006, https://doi.org/10.1029/2006GB002907, 2007.

Dunne, J. P., Hales, B., and Toggweiler, J. R.: Global calcite cycling constrained by sediment preservation controls, Global Biogeochem. Cy., 26, GB3023, https://doi.org/10.1029/2010GB003935, 2012.

Dutkiewicz, A., Müller, R. D., O’Callaghan, S., and Jónasson, H.: Census of seafloor sediments in the world's ocean, Geology, 43, 795-798, https://doi.org/10.1130/G36883.1, 2015.

Etheridge, D. M., Steele, L. P., Langenfelds, R. L., Francey, R. J., Barnola, J.-M., and Morgan, V. I.: Natural and anthropogenic changes in atmospheric $\mathrm{CO}_{2}$ over the last 1000 years from air in Antarctic ice and firn, J. Geophys. Res.-Atmos., 101, 41154128, https://doi.org/10.1029/95JD03410, 1996.

Field, C. B., Behrenfeld, M. J., Randerson, J. T., and Falkowski, P.: Primary Production of the Biosphere: Integrating Terrestrial and Oceanic Components, Science, 281, 237-240, https://doi.org/10.1126/science.281.5374.237, 1998.

Flato, G., Marotzke, J., Abiodun, B., Braconnot, P., Chou, S., Collins, W., Cox, P., Driouech, F., Emori, S., Eyring, V., Forest, C., Gleckler, P., Guilyardi, E., Jakob, C., Kattsov, V., Reason, C., and Rummukainen, M.: Evaluation of Climate Models, book section 9, Cambridge University Press, Cambridge, United Kingdom and New York, NY, USA, 741-866, https://doi.org/10.1017/CBO9781107415324.020, 2013.

Ganopolski, A. and Brovkin, V.: Simulation of climate, ice sheets and $\mathrm{CO}_{2}$ evolution during the last four glacial cycles with an Earth system model of intermediate complexity, Clim. Past, 13, 1695-1716, https://doi.org/10.5194/cp-13-1695-2017, 2017.

Gnanadesikan, A.: A global model of silicon cycling: Sensitivity to eddy parameterization and dissolution, Global Biogeochem. Сy., 13, 199-220, https://doi.org/10.1029/1998GB900013, 1999.

Goddéris, Y. and Joachimski, M. M.: Global change in the Late Devonian: modelling the Frasnian-Famennian short-term carbon isotope excursions, Palaeogeogr. Palaeocl., 202, 309-329, https://doi.org/10.1016/S0031-0182(03)00641-2, 2004.

Heinze, C., Maier-Reimer, E., Winguth, A. M. E., and Archer, D.: A global oceanic sediment model for long-term climate studies, Global Biogeochem. Cy., 13, 221-250, https://doi.org/10.1029/98GB02812, 1999.

Henson, S. A., Sanders, R., and Madsen, E.: Global patterns in efficiency of particulate organic carbon export and transfer to the deep ocean, Global Biogeochem. Cy., 26, GB1028, https://doi.org/10.1029/2011GB004099, 2012.

Hülse, D., Arndt, S., Wilson, J. D., Munhoven, G., and Ridgwell, A.: Understanding the causes and consequences of past marine carbon cycling variability through models, Earth-Sci. Rev., 171, 349-382, https://doi.org/10.1016/j.earscirev.2017.06.004, 2017.

Hurrell, J. W., Holland, M. M., Gent, P. R., Ghan, S., Kay, J. E., Kushner, P. J., Lamarque, J.-F., Large, W. G., Lawrence, D., Lindsay, K., Lipscomb, W. H., Long, M. C., Mahowald, N., 
Marsh, D. R., Neale, R. B., Rasch, P., Vavrus, S., Vertenstein, M., Bader, D., Collins, W. D., Hack, J. J., Kiehl, J., and Marshall, S.: The Community Earth System Model: A Framework for Collaborative Research, B. Am. Meteorol. Soc., 94, 13391360, https://doi.org/10.1175/BAMS-D-12-00121.1, 2013.

Jahn, A., Lindsay, K., Giraud, X., Gruber, N., Otto-Bliesner, B. L., Liu, Z., and Brady, E. C.: Carbon isotopes in the ocean model of the Community Earth System Model (CESM1), Geosci. Model Dev., 8, 2419-2434, https://doi.org/10.5194/gmd-8-2419-2015, 2015.

Jahnke, R. A.: The global ocean flux of particulate organic carbon: Areal distribution and magnitude, Global Biogeochem. Cy., 10, 71-88, https://doi.org/10.1029/95GB03525, 1996.

Jungclaus, J. H., Lorenz, S. J., Timmreck, C., Reick, C. H., Brovkin, V., Six, K., Segschneider, J., Giorgetta, M. A., Crowley, T. J., Pongratz, J., Krivova, N. A., Vieira, L. E., Solanki, S. K., Klocke, D., Botzet, M., Esch, M., Gayler, V., Haak, H., Raddatz, T. J., Roeckner, E., Schnur, R., Widmann, H., Claussen, M., Stevens, B., and Marotzke, J.: Climate and carbon-cycle variability over the last millennium, Clim. Past, 6, 723-737, https://doi.org/10.5194/cp-6-723-2010, 2010.

Kump, L. R., Brantley, S. L., and Arthur, M. A.: Chemical Weathering, Atmospheric $\mathrm{CO}_{2}$, and Climate, Annu. Rev. Earth Pl. Sc., 28, 611-667, https://doi.org/10.1146/annurev.earth.28.1.611, 2000.

Kurahashi-Nakamura, T., Paul, A., and Losch, M.: Dynamical reconstruction of the global ocean state during the Last Glacial Maximum, Paleoceanography, 32, 326-350, https://doi.org/10.1002/2016PA003001, 2017.

Kurahashi-Nakamura, T., Paul, A., Munhoven, G., Merkel, U., and Schulz, M.: Newly developed model code and scripts for the coupling of CESM1.2 and MEDUSA, PANGAEA, https://doi.org/10.1594/PANGAEA.905821, 2019.

Lauvset, S. K., Key, R. M., Olsen, A., van Heuven, S., Velo, A., Lin, X., Schirnick, C., Kozyr, A., Tanhua, T., Hoppema, M., Jutterström, S., Steinfeldt, R., Jeansson, E., Ishii, M., Perez, F. F., Suzuki, T., and Watelet, S.: A new global interior ocean mapped climatology: the $1^{\circ} \times 1^{\circ}$ GLODAP version 2, Earth Syst. Sci. Data, 8, 325-340, https://doi.org/10.5194/essd-8-3252016, 2016.

Laws, E. A., D’Sa, E., and Naik, P.: Simple equations to estimate ratios of new or export production to total production from satellite-derived estimates of sea surface temperature and primary production, Limnol. Oceanogr., 9, 593-601, https://doi.org/10.4319/lom.2011.9.593, 2011.

Lee, K.: Global net community production estimated from the annual cycle of surface water total dissolved inorganic carbon, Limnol. Oceanogr., 46, 1287-1297, https://doi.org/10.4319/1o.2001.46.6.1287, 2001.

Lindsay, K., Bonan, G. B., Doney, S. C., Hoffman, F. M., Lawrence, D. M., Long, M. C., Mahowald, N. M., Keith Moore, J., Randerson, J. T., and Thornton, P. E.: Preindustrial-Control and Twentieth-Century Carbon Cycle Experiments with the Earth System Model CESM1(BGC), J. Climate, 27, 8981-9005, https://doi.org/10.1175/JCLI-D-12-00565.1, 2014.

Ma, S., Tao, Z., Yang, X., Yu, Y., Zhou, X., Ma, W., and Li, Z.: Estimation of Marine Primary Productivity From Satellite-Derived Phytoplankton Absorption Data, IEEE J. Sel. Top. Appl.,
7, 3084-3092, https://doi.org/10.1109/JSTARS.2014.2298863, 2014.

Marchal, O., Stocker, T. F., and Joos, F.: A latitude-depth, circulation-biogeochemical ocean model for paleoclimate studies. Development and sensitivities, Tellus B, 50, 290-316, https://doi.org/10.3402/tellusb.v50i3.16130, 1998.

Matsumoto, K., Sarmiento, J. L., and Brzezinski, M. A.: Silicic acid leakage from the Southern Ocean: A possible explanation for glacial atmospheric $p \mathrm{CO}_{2}$, Global Biogeochem. Cy., 16, 1031, https://doi.org/10.1029/2001GB001442, 2002.

Mayorga, E., Seitzinger, S. P., Harrison, J. A., Dumont, E., Beusen, A. H., Bouwman, A., Fekete, B. M., Kroeze, C., and Drecht, G. V.: Global Nutrient Export from WaterSheds 2 (NEWS 2): Model development and implementation, Environ. Model. Softw., 25, 837-853, https://doi.org/10.1016/j.envsoft.2010.01.007, 2010.

Moore, J. K., Doney, S. C., and Lindsay, K.: Upper ocean ecosystem dynamics and iron cycling in a global threedimensional model, Global Biogeochem. Cy., 18, GB4028, https://doi.org/10.1029/2004GB002220, 2004.

Moore, J. K., Lindsay, K., Doney, S. C., Long, M. C., and Misumi, K.: Marine Ecosystem Dynamics and Biogeochemical Cycling in the Community Earth System Model [CESM1(BGC)]: Comparison of the 1990s with the 2090s under the RCP4.5 and RCP8.5 Scenarios, J. Climate, 26, 9291-9312, https://doi.org/10.1175/JCLI-D-12-00566.1, 2013.

Munhoven, G.: Glacial interglacial rain ratio changes: Implications for atmospheric $\mathrm{CO}_{2}$ and ocean sediment interaction, Deep-Sea Res. Pt. II, 54, 722-746, https://doi.org/10.1016/j.dsr2.2007.01.008, 2007.

Norris, R. D., Turner, S. K., Hull, P. M., and Ridgwell, A.: Marine Ecosystem Responses to Cenozoic Global Change, Science, 341, 492-498, https://doi.org/10.1126/science.1240543, 2013.

Ragueneau, O., Tréguer, P., Leynaert, A., Anderson, R. F., Brzezinski, M. A., DeMaster, D. J., Dugdale, R. C., Dymond, J., Fischer, G., François, R., Heinze, C., Maier-Reimer, E., Martin-Jézéquel, V., Nelson, D. M., and Quéguiner, B.: A review of the Si cycle in the modern ocean: recent progress and missing gaps in the application of biogenic opal as a paleoproductivity proxy, Global Planet. Chang., 26, 317-365, https://doi.org/10.1016/S09218181(00)00052-7, 2000.

Ridgwell, A.: Interpreting transient carbonate compensation depth changes by marine sediment core modeling, Paleoceanography, 22, PA4102, https://doi.org/10.1029/2006PA001372, 2007.

Ridgwell, A. and Hargreaves, J. C.: Regulation of atmospheric $\mathrm{CO}_{2}$ by deep-sea sediments in an Earth system model, Global Biogeochem. Cy., 21, GB2008, https://doi.org/10.1029/2006GB002764, 2007.

Ridgwell, A. and Zeebe, R. E.: The role of the global carbonate cycle in the regulation and evolution of the Earth system [rapid communication], Earth Planet. Sc. Lett., 234, 299-315, https://doi.org/10.1016/j.epsl.2005.03.006, 2005.

Seiter, K., Hensen, C., Schröter, J., and Zabel, M.: Organic carbon content in surface sediments-defining regional provinces, Deep-Sea Res. Pt. I, 51, 2001-2026, https://doi.org/10.1016/j.dsr.2004.06.014, 2004.

Seitzinger, S. P., Mayorga, E., Bouwman, A. F., Kroeze, C., Beusen, A. H. W., Billen, G., van Drecht, G., Dumont, E., Fekete, B. M., Garnier, J., and Harrison, J. A.: 
Global river nutrient export: A scenario analysis of past and future trends, Global Biogeochem. Cy., 24, GB0A08, https://doi.org/10.1029/2009GB003587, 2010.

Shields, C. A., Bailey, D. A., Danabasoglu, G., Jochum, M., Kiehl, J. T., Levis, S., and Park, S.: The Low-Resolution CCSM4, J. Climate, 25, 3993-4014, https://doi.org/10.1175/JCLI-D-1100260.1, 2012.

Siegel, D. A., Buesseler, K. O., Doney, S. C., Sailley, S. F., Behrenfeld, M. J., and Boyd, P. W.: Global assessment of ocean carbon export by combining satellite observations and food-web models, Global Biogeochem. Cy., 28, 181-196, https://doi.org/10.1002/2013GB004743, 2014.

Sigman, D. M. and Boyle, E. A.: Glacial/interglacial variations in atmospheric carbon dioxide, Nature, 407, 859-869, 2000.

Soetaert, K., Middelburg, J. J., Herman, P. M. J., and Buis, K.: On the coupling of benthic and pelagic biogeochemical models, Earth-Sci. Rev., 51, 173-201, https://doi.org/10.1016/S00128252(00)00004-0, 2000.

Stammer, D., Balmaseda, M., Heimbach, P., Köhl, A., and Weaver, A.: Ocean Data Assimilation in Support of Climate Applications: Status and Perspectives, Ann. Rev. Mar. Sci., 8, 491-518, https://doi.org/10.1146/annurev-marine-122414-034113, 2016.
Tréguer, P., Nelson, D. M., Van Bennekom, A. J., DeMaster, D. J., Leynaert, A., and Quéguiner, B.: The Silica Balance in the World Ocean: A Reestimate, Science, 268, 375-379, https://doi.org/10.1126/science.268.5209.375, 1995.

Tréguer, P. J. and De La Rocha, C. L.: The World Ocean Silica Cycle, Annu. Rev Mar. Sci., 5, 477-501, https://doi.org/10.1146/annurev-marine-121211-172346, 2013.

Tschumi, T., Joos, F., Gehlen, M., and Heinze, C.: Deep ocean ventilation, carbon isotopes, marine sedimentation and the deglacial $\mathrm{CO}_{2}$ rise, Clim. Past, 7, 771-800, https://doi.org/10.5194/cp-7771-2011, 2011.

Yamanaka, Y. and Tajika, E.: The role of the vertical fluxes of particulate organic matter and calcite in the oceanic carbon cycle: Studies using an ocean biogeochemical general circulation model, Global Biogeochem. Cy., 10, 361-382, https://doi.org/10.1029/96GB00634, 1996.

Yool, A., Popova, E. E., and Anderson, T. R.: MEDUSA-2.0: an intermediate complexity biogeochemical model of the marine carbon cycle for climate change and ocean acidification studies, Geosci. Model Dev., 6, 1767-1811, https://doi.org/10.5194/gmd6-1767-2013, 2013. 